\title{
ВЗАИМОСВЯЗЬ СТРУКТУРА - АКТИВНОСТЬ ИНГИБИТОРОВ ПРОТЕИНКИНАЗЫ И ПРОИЗВОДНЫХ ПИРИМИДИН-4-1(Н)-ОНА
}

\author{
М.В. Черников, А.В. Мамлеев
}

Кафедра фармакологии с курсом клинической фармакологии Пятигорский медико-фармацевтический институт - филиал ФГБОУ ВО ВолгГМУ 357532 , Россия, Ставропольский край, г.Пятигорск, пр. Калинина, 11.

DOI: 10.19163/MedChemRussia2021-2021-68

E-mail:mamaev.ma00@mail.ru

Практически все сердечно-сосудистые, эндокринные и др. заболевания сопряжены с эндотелиальной дисфункцией (ЭД) [1]. В регуляции активности eNOS-эндотелиальной системы синтеза окида азота большая роль отводится протеинкиназе С (ПКС) [2]. Исследуемая группа веществ представляет собой производные пиримидин-4-1(Н)-она (см. рисунок), которые по результатам прогноза с помощью программ молекулярного докинга показали различную тропность к активным центрам ПКС. Среди ряда исследуемых производных выявляли соединения-лидеры на основании данных по влиянию на вазодилатирующую и антиагрегационную функции эндотелия на экспериментальной модели ЭД, вызванной недостаточностью половых гормонов (НПГ). Для соединения-лидера проводили оценку активности ПКС и еNOS с помощью ИГХ- и ИФА - методов анализа.<smiles>[R]C=Cc1nc(=O)c(-c2ccccc2)c(C)n1-c1ccc(S(N)(=O)=O)cc1</smiles>

2-Стирилпроизводные 4-(2,6-диметил-4-оксо-5-фенил-4Н-пиримидин-1-ил)-бензсульфамида

Лидером по влиянию на вазодилатирующую и антиагрегационную функции эндотелия является вещество с шифром PMS4OH, которое увеличивало AX-стимулированную скорость кровотока в 1,56 раз ( $<<0,01)$, а степень и скорость агрегации вызванной введением АДФ снижало в 2,16 ( $\mathrm{P}<0,01)$ и в 5,13 ( $<<0,01)$ раз соответственно, по сравнению с группой негативного контроля. Исходя из молекулярных прогнозов наиболее выраженно связываться с активными центрами ПКС будет соединение с шифром PMS4OH (plC $\mathrm{C}_{50}=-1,3 ; \mathrm{IC}_{50}$, нM = 21). ИФА подтвердил фармакологические тесты и данные молекулярного прогноза и показал, что введение PMS4OH животным с ЭД приводит к увеличению концентрации eNOS в 1,87 раз $(P \leqslant 0,02)$ и снижению уровня ПКС в 1,92 раза $(P \leqslant 0,05)$, по сравнению с группой негативного контроля.

\section{Литература}

[1] Blood Pressure Reduction is Associated with the Changes in Oxidative Stress and Endothelial Activation in Hypertension, Regardless of Antihypertensive Therapy / M. Mihalj [et al.] Kidney Blood Press Res. 2016, 41, 721-735.

[2] Глушко, А.А. Молекулярные мишени для поиска веществ, обладающих эндотелиопротекторными свойствами / А.А. Глушко, А.В. Воронков, М.В. Черников. Биоорганич. Химия., 2014, 40 (5), 515-527. 